\title{
Academicians in Turkey: An Evaluation of Current Status of Academic Staff in Higher Education
}

\author{
${\text { Bertan } \text { Akyol }^{1} \& \text { Filiz Tanrısevdi }}^{2}$ \\ ${ }^{1}$ Aydın Adnan Menderes University, Faculty of Education, Turkey \\ ${ }^{2}$ Ministry of National Education, Turkey \\ Correspondence: Bertan Akyol, Faculty of Education, Aydın Adnan Menderes University, Aydın, Turkey. Tel: \\ 90-505-810-0011. E-mail: bertanakyol@yahoo.com
}

Received: August 13, 2018

doi:10.5539/hes.v8n4p129
Accepted: September 12, 2018

Online Published: October 26, 2018

URL: https://doi.org/10.5539/hes.v8n4p129

\begin{abstract}
The history of Turkish higher education dates back to Turkish nations of 1000 years ago. The beginning of higher education institutions are accepted as madrasahs that continue its existence during the Ottoman period. After the foundation of the Turkish republic, rapid changes and developments have been observed in the higher education like in all fields. Since this period of time, Turkish higher education institutions have been grouped in two categories, which are universities producing information-knowledge and vocational schools training people oriented with employment. Considering the both types of these institutions, the aim of Turkish higher education system is to sustain manpower considering the needs of the nation and the public; provide education and training facilities based on the secondary education; maintain the quality and quantity of scientific researches under the control of universities. In this context, the purpose of this study is to present the certain dimensions of Turkish higher education system, which are academicianship, current facts related to academicianship, the stages in academic career, achievements in academy and the status of women academicians in Turkey. Related documents have been analyzed and the current status of Turkish higher education system has been discussed by concluding the results.
\end{abstract}

Keywords: Turkish higher education, academicians in Turkey, being academician in Turkey, status of Turkish academy

\section{Introduction}

The word "academics" derives from the Greek "Akademia", the small olive grove in Athens where Plato taught his students. Plato's school for higher education was called "Akademos." Here, Plato and his students discussed various subjects such as mathematics, natural sciences, and the best civil order. While he was teaching at Akademos, Plato wrote his famous Republic, which was the written quest for the best civil order. In addition to Plato's (428-347 B.C.E) school Akademos (387 B.C.E), Aristotle's (384-322 B.C.E) school Lyceum (or Gymnasium) [334 B.C.E] and Alexander the Great's (356-323 B.C.E) school Museum (330 B.C.E) in Alexandria were the examples of higher education institutions in the ancient world (Erdem, 2006; Balon et al., 2010).

Universities are knowledge-producing institutions. Universities do not only produce knowledge but they also teach, present, and distribute it. These four functions are the reasons for the existence of universities. Universities produce knowledge by means of research and development activities, teach by means of educational activities, present knowledge by means of consultancy, and distribute it by means publications (Balon et al., 2010). In the light of this information, we can define the word academician as a professional title for people who teach at universities, do research, produce and distribute knowledge.

\section{Methodology}

The situation of academicians in Turkish universities is examined by literature review. The scope of the study is the universities in Turkey. This study seeks to explain who an academician is and what the characteristics of academicians are. Using the necessity of academic freedom to pursue research as point of departure, the study focuses on certain concepts such as academic autonomy and freedom and explores the practices that prompt people to an academic career. Finally, this study tackles the problems experienced by academicians in Turkey, especially by women. 


\section{Academicianship, Related Concepts and the Current Status in Turkey}

There are two prevailing and opposing views about academicianship. While the first view accepts academicianship as a profession, the second one refuses this classification. The former suggests that academicians share some common values, some of which are academic liberty, individual autonomy, professional collaboration, and orientation towards searching for facts. The latter advocates that academicianship is composed of various professional sub-branches, each having their distinct characteristics. Therefore, academicianship cannot be treated with a holistic view (Celep \& Tülübaş, 2005).

Dill (1982) maintains the first view. He believes academicianship is a profession which contains teaching, research, and service. Academicians interact with various sectors in their academic activities. Dill (1982) demonstrates elements of academicianship in the following figure for a better explanation of the academic activities and interactions.

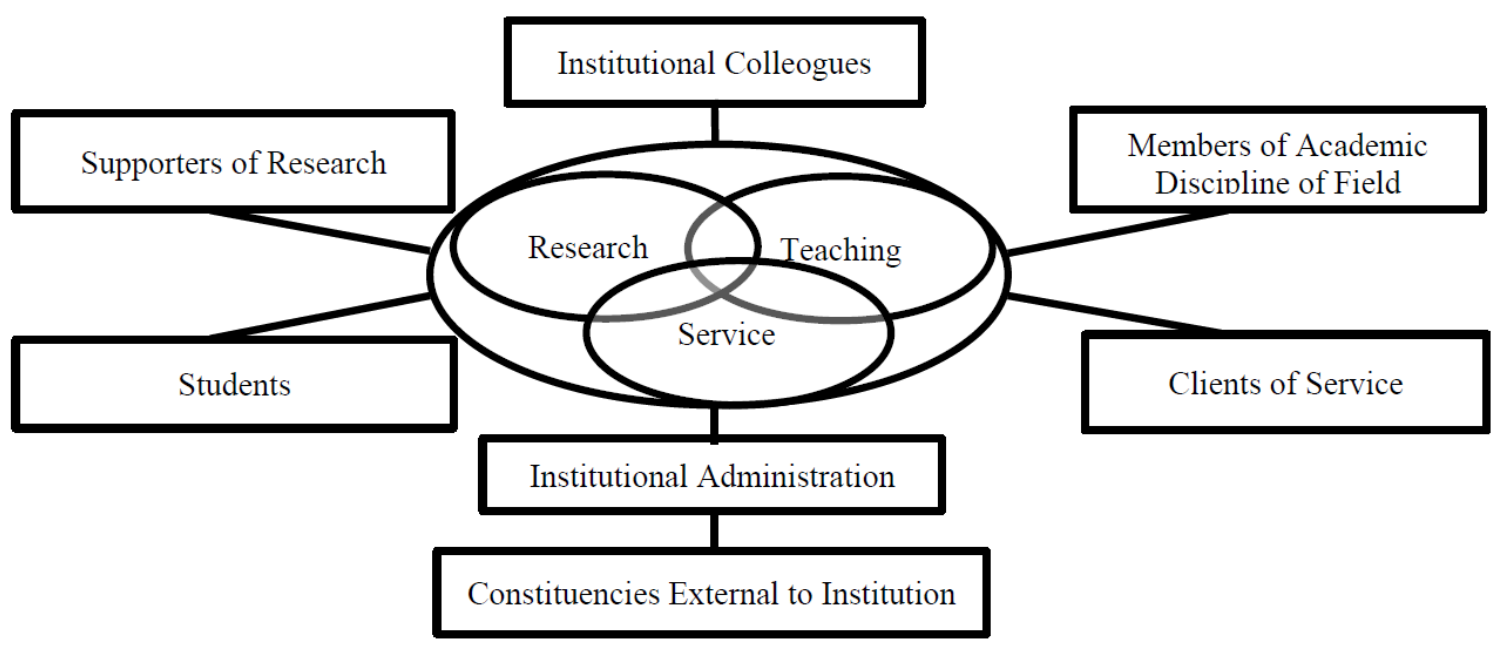

Figure 1. The Elements of Academic Profession

Source: Dill, 1982

Bilgili (2016) defines academic autonomy - a concept highly relevant to academic profession - as "having liberty to do research in accordance with scientific, legal, and ethical rules." As long as the responsibilities of scientists are identified by ethical codes; scientists can claim any special rights beyond other citizens' rights (Edsall, 1975).

According to Bilgili (2016), the following conditions must be present before we can thoroughly discuss scientific autonomy: (1) freedom to choose research topic and methods, (2) absence of restrictive impositions such as guardianship, hierarchy, command and instructions inflicted by local and national administrators, (3) freedom to express ideas without violating the rules and regulations, (4) access to funding for research and development activities.

Universities must encourage free debate and critical thinking. For that to happen, universities must have academic autonomy on an institutional level. Academic autonomy enhances academic freedom; this, in turn, leads to freedom in scientific studies, self-sufficiency in designing curricula and exam schedules, scientific discipline, self-audit and auto-control at universities. However, a number of external pressure mechanisms in academy such as accountability, massification, administrative audit, and decrease in resources are now being used more and more frequently all over the world (Mok \& Jiang, 2016). Academic freedom is under attack in many countries. Academicians are even being arrested in some countries because of their studies. Seen in this light, it is hard to say that freedom to produce academic studies is guaranteed globally (Altbach, 2000a). In addition to being damaged by external pressure, academic autonomy is also influenced by institutional structure and academic conflicts (Aktan, 2003).

In Turkey, the ways academicians get under external pressure might be slightly different from those in other countries. This is caused by the influence of politics on universities. This political influence starts with the choice of the location of a university. Also, the selection of administrative staff and academicians might be under the same influence. A number of external and institutional sanctions are imposed upon universities during the process decision-making (Arap, 2010). 
Turkish language poses the problem of ambiguous connotations of academic freedom. Generally academic freedom, academic autonomy, and scientific autonomy are used interchangeably (Seggie \& Gökbel, 2015). Özipek (2001) states that academic freedom concept can be discussed in terms of individual freedom and academic freedom. Özipek also maintains that academic freedom can be obtained when control over research is reduced to minimum. Therefore, academic freedom in institutional sense is the protection of academicians against any interference from lawmakers and politicians.

As one of the most important developments about academic freedom, Lima Declaration was published on September 6, 1988 (the 40th anniversary of Universal Declaration of Human Rights) by World University Service with the full title The Lima Declaration on Academic Freedom and Autonomy of Institutions of Higher Education.

In Lima Declaration (1988) academic freedom is defined as "the freedom of members of the academic community, individually or collectively, in the pursuit, development and transmission of knowledge." In Article 3 , academic freedom is described as "an essential precondition" for education, research, publication, and service functions of higher education institutions. All members of the academic community are entitled to the right to function without fear of repression from governments or other sources.

In Turkey academic freedom is usually addressed within the context of university autonomy because it is assumed that university autonomy can lead to academic freedom. Another reason for this association is the fact that universities have been a major part of political conflicts in Turkey. Also, the Council of Higher Education has evolved into a centralized structure and thus confirmed that university autonomy connotes academic freedom (Seggie \& Gökbel, 2015).

Turkish Higher Education Law No. 2547 does not protect academic freedom completely. Although there have been recent changes in this law, academic freedom still needs to be legally protected in a more comprehensive way. On the other hand, it takes much more than laws to guarantee academic freedom. The society clearly needs a change of mindset on a cultural level for academic freedom to be maintained (Özipek, 2001). Similarly, Kayrooz et al. (2001) state that academic freedom can be achieved with a strong social structure.

It is evident that YÖK (Council of Higher Education), which was established in 1981 with the Law No. 2547, cannot administer rapidly-growing higher education institutions efficiently. Thus, it needs to go through a reconstruction for executive and financial autonomy at universities. Academicians must be protected from all kinds of external pressure by means of financial autonomy and academic freedom (Akyol \& Arslan, 2014).

\subsection{Facts and Figures about the Academicians in Turkey}

As societies go through changes in arts, health, economy, and culture; education has been drastically affected by these changes. Higher education institutions, with their mission of producing brainpower, hold a central position in this process (Odabaş1 et al., 2010).

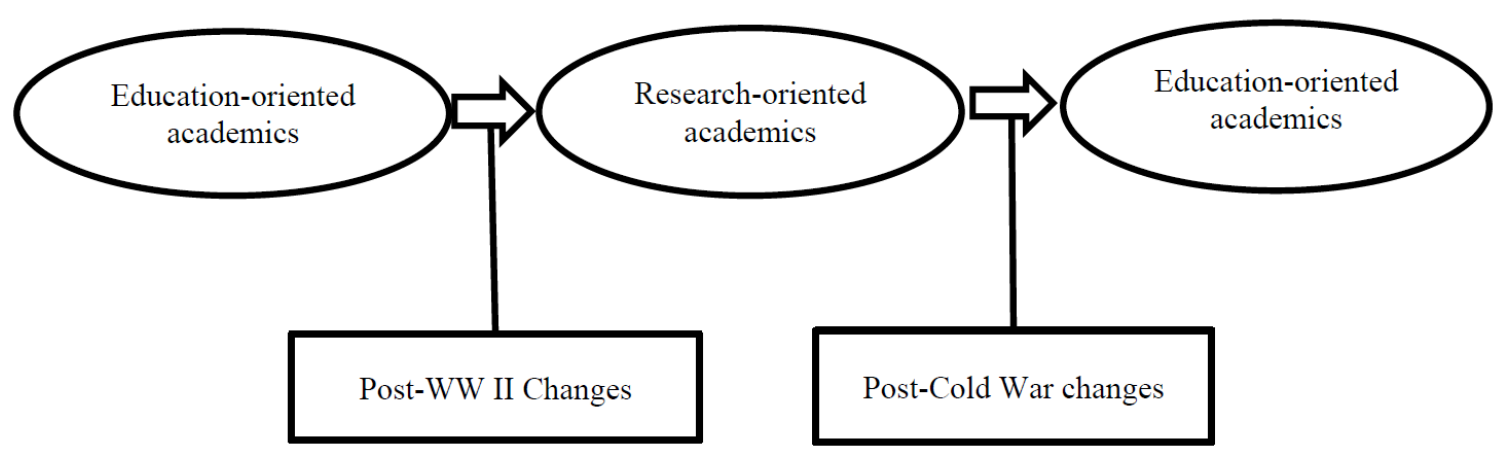

Figure 2. Two Cycles of Changes in The History of Higher Education

Source: Odabaşı et. al., 2010

As shown in Figure 2, two post-war periods caused changes in higher education. Higher education first evolved from being education-oriented to being research-oriented. Then it gravitated back to education-oriented tradition (Cuban 1999). The concepts of academicianship and academic freedom are still evolving, especially due to recent technological developments, the influence of capital on universities, and emergence of new university models (Odabaşı et. al., 2010). 
In the academic year 1930-1931, 2.167 students were studying in İstanbul Darülfunun (renamed as İstanbul University in 1933). The number of university students increased to 11.000 by 1943 . In 1950 , there were three universities in Turkey. By 1973, there were twelve. The number of university students was 322.320 in 1984. In 2011, there were 3.817.086 university students in Turkey (Günay \& Günay, 2011; Sargın, 2007).

By 2018, the number of university students had risen to 7.560 .371 (Table 1). The rapid increase in the number of student enrollment to universities is thought to be caused by new universities, distance education programs, and open education faculties.

Table 1. The Number of Students Enrolled in Higher Education, 2017-2018

\begin{tabular}{llll}
\hline & State University & Private University & Total \\
\hline Male & 3.740 .669 & 306.633 & 4.047 .302 \\
Female & 3.223 .234 & 289.835 & 3.513 .069 \\
Total & 6.963 .903 & 596.468 & 7.560 .371 \\
\hline
\end{tabular}

Source: YÖK, 2018a

The number of universities increase rapidly as well. During the period between 2008 and 2009, 46 new universities were founded, hence the number of universities rose to 139 by 2009 (Akyol \& Arslan, 2014). This number once again rose to 186 in 2018 (YÖK, 2018a).

This upward movement in the number of students and universities is accompanied by an increase in the number of academicians. From the academic year 1923-1924 to 1999-2000, the number of academicians increased from 307 to 63.866 (Baskan, 2001). The number was 158.098 by the academic year 2017-2018. The number of academicians, along with their titles and institutions, is shown in Table 2.

Table 2. Numbers of Academic Positions, 2017-2018

\begin{tabular}{lcccccc}
\hline & Professor & Associate professor & Assistant professor & Instructor & Research assistant & Total \\
\hline Total & 24640 & 14.456 & 37.520 & 35.484 & 45.998 & 158.098 \\
State University & 20.879 & 12.728 & 30.274 & 28.114 & 42.694 & 134.689 \\
Private University & 3.756 & 1.725 & 7.215 & 7.087 & 3.304 & 23.087 \\
Private Vocational School & 5 & 3 & 31 & 283 & - & 322 \\
\hline
\end{tabular}

Source: YÖK, 2018a

\subsection{Academic Career Stages and the Current Status in Turkey}

Graduate education is programmed education which trains scientists and researchers; and provides high-grade human resources. Similar to master-apprentice relationship, graduate education requires selection of favorable students by faculty members (Bülbül, 2003). Delamont, Atkinson and Parry (2004) agree with master-apprenticeship simile and state that compatibility between graduate or $\mathrm{PhD}$ students and their supervisors during their research makes a bigger contribution to science.

Universities, with their growing numbers and potentials, need more academicians. However, Turkey differs from developed countries in terms of the number of students who continue their higher education at $\mathrm{PhD}$ level. One of the reasons for this difference is the insufficient number of master and doctorate programs or insufficient placement. Another reason is the risk of unemployment after $\mathrm{PhD}$ education (Mercan, 2016).

Selection of candidates for master and doctorate programs is based on a number of criteria, as there are few vacancies in these programs. Candidates who meet the prespecified conditions are interviewed. Bülbül (2003) shows in a study, which investigates the opinions of academicians at Ankara University on student selection process, that almost all participants in this study state there might be some influences on the objectivity of the jury during the interviews. The major influence could be the priority given to particular students who are familiar with the jury since their undergraduate education.

Table 3. Numbers of Master's and PhD Students, 2017-2018

\begin{tabular}{llllll}
\hline \multicolumn{2}{l}{ Number of master's students } & \multicolumn{3}{c}{ Number of PhD students } \\
\hline Female & Male & Total & Female & Male & Total \\
178.892 & 275.781 & 454.673 & 40.487 & 54.613 & 95.100 \\
\hline
\end{tabular}

Source: YÖK, 2018 
Table 3 shows that master's students outnumber PhD students. It can be deduced that the reasons for leaving the graduate education are insufficient student placement, insufficient student funding, risk of unemployment after $\mathrm{PhD}$, and possibility of bias during the interviews. Nevertheless, the number of higher education institutions in Turkey is rising rapidly. This leads to a growing need for academicians. The primary solution is to develop training programs for academic candidates (YÖK, 2007; 2017).

Finding scholarship during graduate education is of utmost importance, since there is no job guarantee for students during and after their education. Turkish government, as well as a number of organizations, finance graduate studies of unemployed students. However, these scholarships remain insufficient. Few students can be entitled to receive funding based on particular criteria (Mercan, 2016).

The primary institution which sends students abroad for master's and $\mathrm{PhD}$ education is the Ministry of National Education. The ministry sent 1755 students abroad between 1994 and 2005, in accordance with the Law No. 1416. The efficiency of this program remained at the rate of $52 \%$ which is quite low. The determining factor for this low rate is thought to be the inadequacy of foreign language skills of the participants (YÖK, 2007).

Another program, which was developed by YÖK for training academicians in accordance with the Law No. 2547 Article 33, sent 3745 research assistants between 1987 and 2004 to 29 countries. About 50\% of the participants visited the USA, $38 \%$ visited the UK, and $12 \%$ were sent to other countries. The success rates based on the completion of the doctorate programs and the number of students receiving $\mathrm{PhD}$ scholarships in a foreign country are shown in Table 4.

Table 4. International PhD Scholarships

\begin{tabular}{lllllll}
\hline Institution & Legal Basis & Term & Number of Scholars & Completed & Continuing & Success \% \\
\hline Ministry of National Education & 1416 & $1994-2005$ & 1755 & $357 \mathrm{PhD}$ & 362 & 60,34 \\
& & & & 340 Master's & & \\
Council of Higher Education & 2547 & $1987-2004$ & 3745 & 2132 & 714 & 70,26 \\
TÜBiTAK & NATO-A.1 & $1986-2005$ & 384 & 227 & 28 & 66,40 \\
& Integrated & $1995-2005$ & 238 & 178 & 58 & 99,16 \\
TÜBA & Integrated & $1995-2005$ & 157 & 116 & 24 & 89,17 \\
\hline
\end{tabular}

Source: TÜBA (Turkish Academy of Sciences), 2006

A third method of training academicians is to commission research assistants to visit developed universities for their graduate education. In accordance with Law No. 2547 Article 35, research assistants from developing universities have been commissioned in developed universities. 3340 assistants are being trained through this program. Yet, these programs are still insufficient to meet the academic needs in Turkey (TÜBA, 2006).

\subsection{Achievements in Academy and the Current Status in Turkey}

Academic profession is based on constant self-improvement, hence its difficulty. Academy in Turkey has been under pressure recently, so two major elements of academy - academic freedom and academic autonomy - are being threatened (Y1ldiz, 2014). The difficulty of this profession is a source of anxiety for academicians and the pressure from various sources increases the level of anxiety.

Before 1980, academic career would appeal to successful university students. Today, academic professions offer particular status, but fail at providing enough income (Table 5). As a result, the profession is losing its appeal and successful students are turning towards different professions. When these circumstances are considered, it is highly likely that there will be many vacancies in academic professions (Tomruk, 2014).

As prospective academicians start their career as research assistants, they usually have to consent to teach without any payment, prepare exam questions, grade papers, and complete endless tasks in order to secure a seat at universities and receive letters of recommendations from professors. Meanwhile, they fail at doing research and publish original studies (Tomruk, 2014). Young research assistants have to deal with high levels anxiety right at the beginning of their career.

The anxiety levels continue to increase when research assistants become faculty members. In a study conducted by Yildız (2014), faculty members at Mersin University paint a bleak picture about the current status of universities and academicians. Emphasizing the inadequacy of academy in terms of quality, the participants express concern over uncertainty and complexity in academic structures. The participants further state that research, as the main goal of universities, is replaced by teaching which has been lacking in quality and serving different purposes (profit seeking, political views etc.). They observe that interpersonal communication and 
relationships are characterized by conflict of interests or mutual benefits.

It is necessary to bring forward the issue of job satisfaction in academy. It is possible to claim that academicians cannot attain job satisfaction unless their physical, spiritual, mental, and social needs are met. Academicians who cannot attain job satisfaction start exhibit negative behaviours such as aggression, accusation, absenteeism, consent, inefficiency, and lack of enthusiasm (Tomruk, 2014). These factors increase the anxiety levels of academicians.

Meeting the needs of academicians for job satisfaction revives the issue of salaries which are still quite low despite an improvement in 2015. Table 5 shows the base salaries of faculty members between 1983 and 2017. The net salaries may vary with each university. Considering the expenses of participating in international events, the salaries are still unsatisfactory.

Table 5. Base Salaries of Faculty Members between 1983 and 2017

\begin{tabular}{lllll}
\hline \multirow{2}{*}{ Years } & \multicolumn{4}{c}{ Base Salaries (US Dollar) * } \\
\cline { 2 - 5 } & Professor (1/4) & Associate Professor (2/1) & Assistant Professor & Research Assistant \\
\hline 1983 & 384 & 294 & 198 & 162 \\
1990 & 1110 & 740 & 581 & 383 \\
1995 & 579 & 443 & 357 & 328 \\
2000 & 898 & 678 & 579 & 431 \\
2001 & 745 & 496 & 452 & 326 \\
2006 & 1708 & 1119 & 908 & 629 \\
2013 & 2170 & 1513 & 1437 & 1250 \\
$2017^{* *}$ & 2157 & 1346 & 1304 & 1207 \\
\hline
\end{tabular}

Source: YÖK, 2007; 2013

*US Dollar is calculated through the daily rate.

** 2017 data is calculated by The Law on Higher Education (Law no 2547); Higher Education Personnel Law (Law no 2914); Social Security and General Health Insurance Law (Law no 5510); Civil Servants Law (Law no 657).

Salaries were increased after the Cabinet Decree in 2015 which provided academic incentive (Regulation on Academic Incentive Payments, 2015). The new regulation allowed for supplementary payment for international events and thus encouraged academicians to participate in new scientific activities. It is still necessary to evaluate scientific activities and studies more thoroughly for scientific properties and quality as academic incentive may result in studies high in number but poor in quality.

\subsection{Women in Academy and the Current Status in Turkey}

Science, which helps us understand the universe and serves people, is not monopolized by men. Yet, using the words "science" and "women" in the same sentence has been odd since beginning of the history of science. No seats were available for women in the classes taught by famous ancient philosophers. Only after centuries of struggle could women enter male-dominated world of science (Hasan, 2013).

The most striking example of women's struggle in the history of science is that of Hypatia of Alexandria, daughter of the famous mathematician Theon. Curator of Alexandria Library, a worthy mathematician, astronomer, and Neo-Platonist scientist, Hypatia was killed, dismembered, and burned brutally. During this murder, valuable works at Alexandria Library were also set to fire. This murder and destruction was one of the most shameful crimes against humanity. It will be condemned until the end of history (Uluğbay, 2015; Viney, 2013). As a result of centuries-long struggle, women have gained equal rights to education and research around the world, especially at the beginning of the 21 st century. Inequality and accompanying problems continue to exist in underdeveloped countries (Narmansoy, 2010).

One of the tangible results of women's struggle was the Convention on the Elimination of All Forms of Discrimination against Women (CEDAW), which started to materialize during the World Conference of the International Women's Year held in Mexico City in 1975 and adopted by the United Nations General Assembly in 1979. In 1981, after twenty member states ratified the convention, it entered into force. The main aim of the convention has been to implement comprehensive legal standards for women, secure gender equality in every sphere of life, call for the abolition of all forms of customs and exercises that maintain discrimination against women, and challenge prejudices and stereotypes based on traditional gender roles. This convention is the only internationally binding legal document against gender-based discrimination. Turkey ratified CEDAW in 1985 . The number of state parties by 2016 is 189 (KSGM, 2018). 
Since the early days of Turkish republic and as a result of encouragement of women to participate in social and economic life primarily by Mustafa Kemal Atatürk and by governments, women's involvement in academy has been increasing. On 31 May 1933, Law on the Abolition of Darülfunun and Establishment of a New University by the Ministry of National Education was enacted and women's enrolment at every department was encouraged. The number of women academicians was zero during the first year of the republic. This number increased consistently and the rate of women academicians reached $41 \%$ by 2009. The most striking part of this picture is the fact that the increase in the number of women in academy peaked between 1933 and 1944, after the University Reform of 1933, whereas the rate climbed from $0 \%$ to $7.14 \%$ during the first ten years of the republic (Özkanl1, 2007). As shown in Table 6, the rate reached $44.42 \%$ in 2018.

Table 6. Figures Showing Women Academicians in Turkey (2018, private universities included)

\begin{tabular}{lcccc}
\hline Academic Title & Women & Men & Total & The ratio of women to total number (\%) \\
\hline Professor & 7.696 & 16.944 & 24.640 & 31.23 \\
Associate professor & 5.611 & 8.845 & 14.456 & 38.81 \\
Assistant professor & 15.932 & 21.588 & 37.520 & 42.46 \\
Instructor & 17.806 & 17.678 & 35.484 & 50.18 \\
Research assistant & 23.190 & 22.808 & 45.998 & 50.41 \\
Total & 70.235 & 87.863 & 158.098 & 44.42 \\
\hline
\end{tabular}

Source: YÖK, 2018a

After women's involvement in academy, the number women scientists who are building reputation with their studies has been on the rise. It is observed that most women in academy who made remarkable contributions to science studied at universities on scholarship. All these developments became reality thanks to Ataturk's perspective on science and women (Narmansoy, 2010).

The rate of women in academy is remarkable compared to other countries. However, women's tendency towards pursuing career in "womanly" areas is worrying. Two main areas dominated by women are health and education. The improvement of women's conditions in academy depends on a change in gender-based clustering in professions (Özkanlı, 2007).

Although the general appearance of numbers seems pleasing, Table 6 reveals that the rates of women under the titles of professor and associate professor fall behind those of men. This is caused by the complexity of women's roles imposed upon them by society (Tanrısevdi, 2015). For this problem, White and Özkanlı (2008) offer the solution of establishing a democratic family environment. According to them, the family must run by democracy and the chores must be shared equally. Only then could women be freed from impositions. White and Özkanlı also remind the importance of providing housekeeping and childcare assistance for women academicians.

As the general picture of women's employment in academic professions is examined critically, it is possible to see that the positions held by women are characterized by sexual division of labor. The fact women are involved in academic professions more than other professions, does not lead to higher rates of representation in administrative positions. The higher the stage of academic hierarchy, the lower the rates of women administrators. This proves that women have to face the glass ceiling obstacle in academy (Şentürk, 2015).

\section{Conclusion}

University education which produces quality manpower can be considered a key point of progress due to the relationship between progress and education. In the 21 st century, the humanity evolved from industrial societies to information societies (Thurow, 1999). Therefore, muscle power is replaced by brainpower. Universities are being reformed in order to produce sufficient brainpower. Universities are focusing more on research-based activities while they are hiring part-time instructors for teaching. This leads to an increase in research and development activities. In other words, academicians can focus on their actual work, i.e. scientific studies (Altbach, 2000b).

Academicians are supposed to be individuals who are able ask questions, do research, and solve problems. Against this expectation, according to İnam (1999), academicians are becoming vain individuals who lack self-criticism due to their narrow point of view, waver between businesses and public service, do homework, and mistake their field of study for the major problems in science.

The number of universities in Turkey is increasing consistently. Therefore, the need for academicians is growing. The rates of training academicians, especially at $\mathrm{PhD}$ level, remain insufficient due to inadequate scholarship 
opportunities. Another problem is the increasing amount of teaching per capita. The load of lessons give a teaching-oriented character to academy. In accordance with the transitioning to research-based universities all around the world, YÖK and the Ministry of Law have been establishing research universities with the help of "Mission Differentiation and Specialization Based on Regional Development" project since 2015 (YÖK, 2018b). These works still need to be implemented more rapidly and efficiently.

Today, universities in Turkey have to go under reconstruction in terms of location and function. Not only universities but also academicians and scientists need reconstruction or a quintessential type of humanism. The following conditions should be met before we can talk about a radical reformation at universities (Karaçay \& Mıhçı, 1999):

- More self-reliance on the part of scientists and academicians

- Courage to recognize and solve existing problems

- Cooperation among colleagues and with younger generations

- Adherence to the effort of defining universe and humanity, rather than to unconditional faith.

These steps will definitely help remove at least some of the obstacles in higher education system of Turkey.

\section{References}

Aktan, C. C. (2003). Özlenen Üniversite, Yaşanan Üniversite (The University We Live Is The One We Missed). Ankara: Yeni Türkiye Yayınları. Retrieved from http://www.canaktan.org/egitim/universitereform/aka-ozerklik.htm\#_edn5

Akyol and Arslan (2014). The Evaluation of Higher Education Problems in Turkey. European Scientific Journal, 10(7), 71-84.

Altbach, P. G. (2000a). Academic Freedom: International Realities and Challenges. In P. G. Altbach (Ed.), The Changing Academic Workplace: Comparative Perspectives. Massachusetts: CIHE, Boston College.

Altbach, P. G. (2000b). The Deterioration of The Academic Estate: International Patterns of Academic Work. In P. G. Altbach (Ed.), The Changing Academic Workplace: Comparative Perspectives. Massachusetts: CIHE, Boston College.

Arap, K. S. (2010). Türkiye Yeni Üniversitelerine Kavuşurken: Türkiye'de Yeni Üniversiteler (Turkey Meets its New Universities: New Universities in Turkey and the Rationale Behind the their Foundation). Ankara University SBF Journal, 65(1), 1-29. https://doi.org/10.1501/SBFder_0000002156

Balon, R., Coverdale, J., \& Roberts, L. W. (2010). Academician: What's in a Name?. Academic Psychiatry, 34(3), 169-171. https://doi.org/10.1176/appi.ap.34.3.169

Baskan, G. A. (2001). Türkiye'de Yükseköğretimin Gelişimi (Development of The Higher Education in Turkey). Gazi University Journal of Gazi Educational Faculty, 21(1), 21-32.

Bilgili, A. S. (2016). Üniversitelerde Bilimsel/Akademik Özerklik ve Özgürlük Hakkında Bir Değerlendirme (An Evaluation of Scientific/Academic Auyononmy and Freedom in Universities). Atatürk University Journal of Graduate School of Social Sciences, 20(1), 1-15.

Bülbül, T. (2003). Ankara Üniversitesi Eğitim Bilimleri Fakültesinde Görev Yapan Öğretim Üyelerinin Lisansüstü Öğretme Öğrenci Seçme Sürecine İlişkin Görüşleri (Ankara University Faculty of Educational Sciences Task Position Instructors Graduate Education Teachers Opinions Regarding Student Selection Process). Ankara University Journal of Faculty of Educational Sciences, 36(1-2), 167-174.

Celep, C., \& Tülübaş, T. (2015). Yükseköğretimin Yönetimi. Ankara, Turkey: Nobel Yayıncılık.

Cuban, L. (1999). How Scholars Trumped Teachers: Change Without Reform in University Curriculum, Teaching, and Research, 1890-1990. Teachers College Press.

Delamont, S., Atkinson, P., \& Parry, O. (2004). Supervising the doctorate: A guide to success. England: McGraw-Hill Education.

Dill, D. (1982). The Structure of the Academic Profession: Toward a Definition of Ethical Issues. The Journal of Higher Education, 53(3), 255-267. https://doi.org/10.1080/00221546.1982.11780452

Edsall, J. T. (1975). Scientific Freedom and Responsibility. Science (New Series), 188(4189), 687-693. https://doi.org/10.1126/science.11643270

Erdem, A. R. (2006). Dünyadaki Yükseköğretimin Değişimi (Change of Higher Education in the World). Selçuk University The Journal of Institute of Social Sciences, 15, 299-314. 
Günay, D., \& Günay, A. (2011). 1933'den Günümüze Türk Yükseköğretiminde Niceliksel Gelişmeler (Quantitative Developments in Turkish Higher Education since 1933). Yükseköğretim ve Bilim Dergisi, I(1), 1-22. https://doi.org/10.5961/jhes.2011.001

Hasan, S. (2013). Women of the Scientific Revolution: The Forgotten Scholars (May 2). Young Historians Conference. Paper 18. Retrieved from

https://pdxscholar.library.pdx.edu/cgi/viewcontent.cgi?article=1027\&context=younghistorians

İnam, A. (1999). Akademisyen mi, Ak-Adam-İsyan mı?, Doğu Batı Düşünce Dergisi, 2(7), 147-161.

Karaçay, H., \& Mıhçı, H. (1999). Üniversite, Bilim Adamı ve Akademisyen: Kölelikten Özgürlüğe Doğru (University, Scientist, and Academician: From Slavery to Freedom). Toplum ve Hekim, 14(4), 296-303.

Kayrooz, C., Kinnear, P., \& Preston, P. (2001). Academic Freedom and Commercialisation of Australian Universities Perceptions and experiences of social scientists. The Australia Institute, Discussion Paper Number 37. Retrieved from http://www.tai.org.au/sites/defualt/files/DP37_8.pdf

KSGM (2018). The General Directorate of the Status of Women Directorate General for Status and Problems of Women, Convention on the Elimination of All Forms of Discrimination Against Women. Retrieved from https://kadininstatusu.aile.gov.tr/kaynak/ulusarasi-belgelerkuruluslar/uluslararasi-kuruluslar/birlesmis-milletler

Lima Decleration (1988). Retrieved from https://www.wusgermany.de/sites/wusgermany.de/files/userfiles/WUS-Internationales/wus-lima-englisch.pdf

Mercan, Z. (2016). Decision Making Process in the Academic Career Orientation: Agentic and Communal Perspectives of Turkish Postgraduate Education Scholars (Unpublished master's thesis). İstanbul Bilgi University, İstanbul, Turkey.

Mok, K. H., \& Jiang, J. (2016). Massification of Higher Education: Challenges for Admissions and Graduate Employment In China. In K. H. Mok (Ed.), Managing International Connectivity, Diversity of Learning and Changing Labour Markets. Singapore: Springer.

Narmansoy, G. (2010). Turkish Female Academicians and Their Contributions To Sciences. Gaziantep University Journal of Social Sciences, 9(1), 203-232.

Odabaşı, H. F., Fırat, M., İzmirli, S., Çankaya, S., \& Mısırlı, Z. A. (2010). Being Academician In Globalizing World, Anadolu University Journal of Social Sciences, 10(3), 127-142.

Özipek, B. B. (2001). Akademik Özgürlüğün Anlamı ve Gerekliliği (The Meaning and Need of Academic Freedom). Liberal Düşünce, 24, 185-195. Retrieved from http://www.libertedownload.com/LD/arsiv/24/sayi-24.pdf

Özkanlı, Ö. (2007). The Situation of Academic Women in Turkey. Education and Science, 32(144), 59-70.

Özkanlı, Ö., \& White, K. (2008). Leadership and Strategic Choices: Female Professors in Australia and Turkey. Journal of Higher Education Policy and Management, 30(1), 53-63. https://doi.org/10.1080/13600800701745051

Regulation on Academic Incentive Payments (2015). Cabinet Decree Date: 2015-12-14, Cabinet Decree Number: 2015/8305. Retrieved from http://www.resmigazete.gov.tr/eskiler/2015/12/20151218-4.pdf

Sargın, S. (2007). Türkiye'de Üniversitelerin Gelişim Süreci ve Bölgesel Dağılımı (Development Process and Regional Distribution of University in Turkey). Journal of Süleyman Demirel University Institute of Social Sciences, 3(5), 133-150.

Seggie F. N., \& Gökbel, G. (2015). From Past to Present Academıc Freedom in Turkey, Seta (Foundation For Political, Economic and Social Research) Analysis, May 2015, No: 15. Retrieved from http://file.setav.org/Files/Pdf/20140624165556_gecmisten-gunumuze-turkiye\%E2\%80\%99de-akademik-oz gurluk-pdf.pdf

Şentürk, B. (2015). Nonethemore: An Essay on Female Academics in Turkey. ViraVerita E-Dergi, 2, 1-22.

Tanrısevdi (2015). Glass Ceiling Syndrome Faced by Women Executives in Educational Organizations (Unpublished master's thesis) Adnan Menderes University, Aydın, Turkey.

Thurow, L. C. (1999). Building wealth: The new rules for individuals, companies, and nations in a knowledge-based economy. New York: Harper Collins.

Tomruk, Z. (2014). Sources of Stress, Relationship of Behaviors During Stress and Handling It For Academicians-the Case of Near East University (Unpublished master's thesis). Gazi University, Ankara, 
Turkey.

TÜBA (2006). Türkiye'de Doktora Eğitiminin Durumu Üzerine Görüsler (Opinions on the Status of PhD Training in Turkey). Retrieved from www.emo.org.tr/ekler/f04ac8eadb8a829_ek.doc?tipi=38...X...

Uluğbay, H. (2015). Thoughts on Book Banning. Turkish Librarianship, 29(4), 707-717.

Viney, D. W. (2013). Remembering and Misremembering Hypatia: The Lessons of Agora. The Midwest Quarterly, 54(4), 352-369.

Yıldız, S. (2014). Investigation of faculty members' perception abaot university, profession of acedemician, scientific research, teaching and student concepts via methopors (Unpublished master's thesis). Mersin University, Mersin, Turkey.

YÖK (2007). Türkiye'nin Yükseköğretim Stratejisi (Turkey's Strategy for Higher Education). Retrieved from http://www.yok.gov.tr/documents/10279/30217/yok_strateji_kitabi/27077070-cb13-4870-aba1-6742db37696b

YÖK (2013). Türkiye'de Akademisyenlerin Özlük Haklarının Mevcut Durumu Ve Özlük Haklarının Iyileştirilmesi Raporu (Remediation Report of Current Status of academics and justices of Personal Rights in Turkey). Retrieved from http://www.yok.gov.tr/documents/10279/173480/rapor.pdf/3d4c9bed-c7bb-4c34-9875-c115bc043816

YÖK (2018a). Higher Education Statistics in Turkey, 2017-2018. Retrieved from https://istatistik.yok.gov.tr/

YÖK (2018b). Üniversitelerin Bölgesel Kalkınma Odaklı Misyon Farklılaşması ve İhtisaslaşması (Universities' Regional Development Focused Mission Differentiation and Specialization). Retrieved from http://www.yok.gov.tr/web/guest/yok-ten-universitelere-kalkinma-cagrisi

\section{Copyrights}

Copyright for this article is retained by the author(s), with first publication rights granted to the journal.

This is an open-access article distributed under the terms and conditions of the Creative Commons Attribution license (http://creativecommons.org/licenses/by/4.0/). 